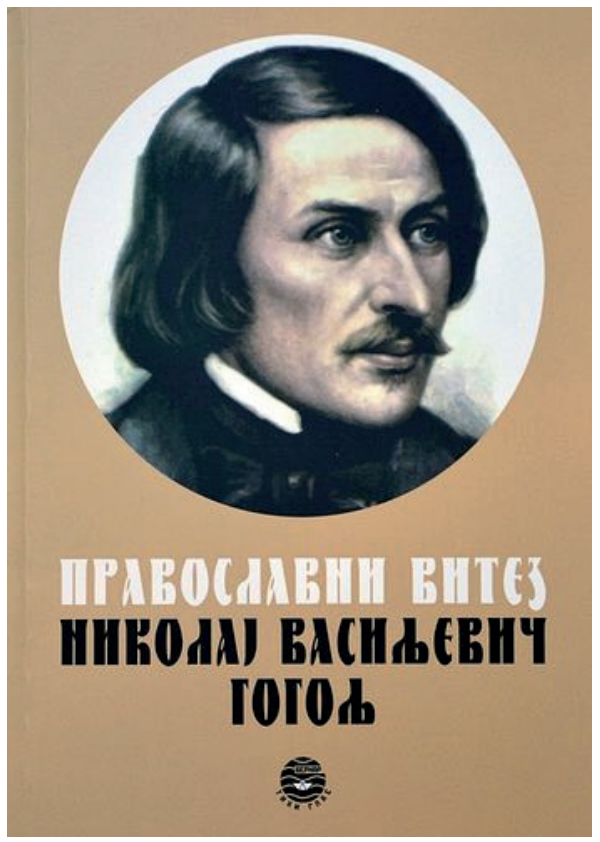

B.A. Boponaes

Православный Гоголь в Сербии

V.A. Voropaev

\title{
Orthodox Gogol in Serbia
}

\section{Православни витез Николај Васиљевич Гогољ / Приредио и превео Ранко Гојковић. Стари Бановци; Београд: Бернар, 2017. 163 с. (Библиотека Тихи глас)}

Издательство «Бернар» в Белграде выпустило в свет книгу «Православный рыцарь Николай Васильевич Гоголь». Подготовил издание известный сербский переводчик, писатель и публицист Ранко Гойкович. Им же написано предисловие: «Николай Васильевич Гоголь как великий апологет Святой Руси». В сборник вошли статьи, посвященные великому русскому писателю, отрывки из его духовно-нравственных сочинений, молитвы, духовное завещание, предсмертные записи. В книгу включены также переписка современников Гоголя и некоторые его письма к разным лицам, в частности к В.Г. Белинскому. В издании помещены работы священномученика Серафима (Чичагова), протопресвитера Василия Зеньковского, деятелей русской эмиграции: философа Ивана Ильина, историка литературы, славяноведа Александра Погодина, писателя и критика Константина Мочульского, а также статьи современных авторов: протоиерея Анатолия Затовского, литературоведов Владимира Воропаева, Игоря Золотусского, социолога и историка русской философии Вадима Сапова.

На состоявшейся недавно 62-й международной книжной ярмарке в Белграде книга о Гоголе вызвала большой интерес; она была представлена на трех стендах (издательства «Бернар», Сербской Православной Церкви и Хиландарского монастыря) и стала одной из самых продаваемых книг. И потому, по словам директора издательства Николи Дробняковича, в скором времени можно ожидать второе издание. В ходе ярмарки издатель подарил книгу «Православный витязь Николай Гоголь» Святейшему Патриарху Иринею, нескольким епископам Сербской Православной Церкви (Далматинской, Крушевацкой, Нишской епархий), митрополиту Амфилохию, настоятелю храма св. Саввы и ряду видных церковных и общественных деятелей.

Во время книжной ярмарки издательство «Бернар» было представлено на государственном телевидении и церковном телевидении Белградского Патриархата. Книга о Гоголе - далеко не первый подобный проект издательства, выпустивше- 
го за последние десять лет более 100 книг русских авторов и ставшего крупнейшим издателем русской литературы в Сербии. В его активе такие известные русские писатели, как Чехов, Бунин, Лесков, Паустовский, Шмелев, Зайцев, Куприн и многие другие. Издания «Бернара» на сербском языке вошли в книжный фонд ряда российских библиотек, включая Российскую государственную библиотеку. В ближайших планах издательства выход книги Владимира Воропаева «Однажды Гоголь...», с которой сербские читатели познакомятся уже весной нынешнего года.

Сведения об авторе:

Владимир Алексеевич Воропаев, доктор филол. наук

профессор

филологический факультет

МГУ имени М.В. Ломоносова
Vladimir A. Voropaev,

Doctor of Philology

Professor

Philological Faculty

Lomonosov Moscow State University

voropaevvl@bk.ru 